\title{
Complex leadership as a way forward for transformational missional leadership in a denominational structure
}

\begin{tabular}{|c|}
\hline $\begin{array}{l}\text { Author: } \\
\text { C.J.P. (Nelus) Niemandt }{ }^{1}\end{array}$ \\
\hline $\begin{array}{l}\text { Affiliation: } \\
\text { 'Department of Science } \\
\text { of Religion and Missiology, } \\
\text { Faculty of Theology, } \\
\text { University of Pretoria, } \\
\text { South Africa }\end{array}$ \\
\hline $\begin{array}{l}\text { Correspondence to: } \\
\text { Nelus Niemandt }\end{array}$ \\
\hline $\begin{array}{l}\text { Email: } \\
\text { nelus@pixie.co.za }\end{array}$ \\
\hline $\begin{array}{l}\text { Postal address: } \\
\text { Private Bag X20, Hatfield } \\
0028 \text {, South Africa }\end{array}$ \\
\hline $\begin{array}{l}\text { Dates: } \\
\text { Received: } 24 \text { Mar. } 2015 \\
\text { Accepted: } 19 \text { May } 2015 \\
\text { Published: } 25 \text { Aug. } 2015\end{array}$ \\
\hline $\begin{array}{l}\text { How to cite this article: } \\
\text { Niemandt, C.J.P., 2015, } \\
\text { 'Complex leadership as a way } \\
\text { forward for transformational } \\
\text { missional leadership in a } \\
\text { denominational structure', } \\
\text { HTS Teologiese Studies/ } \\
\text { Theological Studies 71(3), } \\
\text { Art. \#2951, } 9 \text { pages. http:// } \\
\text { dx.doi.org/10.4102/hts. } \\
\text { v71i3.2951 }\end{array}$ \\
\hline $\begin{array}{l}\text { Copyright: } \\
\text { (C) 2015. The Authors. } \\
\text { Licensee: AOSIS } \\
\text { OpenJournals. This work is } \\
\text { licensed under the Creative } \\
\text { Commons Attribution } \\
\text { License. }\end{array}$ \\
\hline
\end{tabular}

\section{Author:}

C.J.P. (Nelus) Niemandt ${ }^{1}$

Affiliation:

Faculty of Theology,

University of Pretoria,

Correspondence to:

Nelus Niemandt

\section{Email}

Postal address:

Private Bag X20, Hatfield

, South Africa

ived: 24 Mar. 2015

How to cite this article: missional leadership in a denominational structure' eologiese Studies Art. \#2951, 9 pages. http:// dx.doi.org/10.4102/hts.

\section{Copyright:} OpenJournals. This work is licensed under the Creative License.

Read online:

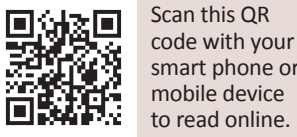

The research investigates the role of leadership in the transformation of denominational structures towards a missional ecclesiology, and focusses on the Highveld Synod of the Dutch Reformed Church. It describes the missional journey of the denomination, and interprets the transformation. The theory of 'complex leadership' in complex systems is applied to the investigation of the impact of leadership on a denominational structure. The theory identifies three mechanisms used by leaders as enablers in emergent, self-organisation systems: (1) Leaders disrupt existing patterns, (2) they encourage novelty, and (3) they act as sensemakers. These insights are applied as a tool to interpret the missional transformation of a denomination.

\section{Introduction}

The growing interest in missional ecclesiology leads to the investigation of the transformation of denominational structures and the role of denominations in the emergence of missional theology. Van Gelder (2008a:42) argues that the missional church conversation has reintroduced a discussion about the very nature of the church. The issue is not about what the church does, but rather about what the church is. This is clearly also the case with the Dutch Reformed Church (DRC) in South Africa. The missional transformation of congregations in the DRC has been described in a number of research studies (e.g. Cordier 2014; Cordier \& Niemandt 2015; Hendriks 2009; Nell 2014; Niemandt 2010; Sheridan \& Hendriks 2013; Van Niekerk 2014). Other research established the missional transformation of denominational structures in the DRC (Niemandt 2014). ${ }^{1}$ The role of transformational leadership in denominations, and an appropriate understanding of leadership that undergirds and facilitates this missional transformation, needs to be investigated and is the subject of this research.

The aim of this mixed methods research (Creswell 2015:2) is to apply the theory of 'complex leadership' developed by Plowman et al. (2007) to missional ecclesiology and missional leadership studies. This is done by way of a case study on the impact of transformational leadership in a denominational structure of the DRC (The Highveld Synod of the DRC [NGK, Sinode Hoëveld]). This research combines participatory action research ${ }^{2}$ (De Vos 1998:265-276, 406-417) and literature study. Integration of the participatory action research and literature study takes the form of merging, explaining, and interpreting (Creswell 2015:7), as well as deducing a new way forward for transformational missional leadership.

\section{The missional narrative of a denominational structure}

The DRC is situated in the Reformed tradition, and has a Presbyterian polity. It is made up of a General Synod (a policy-making structure) and ten regional synods (including the Highveld Synod [Sinode Höeveld]). Every synod has its own regional structure, and has full jurisdiction over its own affairs. Decisions of synods are important in a number of ways: Official decisions, policy documents and vision statements represent a reflection on the dominant language and thus imagination - of the synod. Churches function on various levels, for example, the sermons preached in any given congregation, decisions on the level of the local congregation, decisions of denominational synods, ecumenical decisions, et cetera; and each of these levels allows one to identify various manifestations of church (Coetzee \& Conradie 2012:91). In this research, the focus will be on a denomination as an expression of the institutional church, and the denominational language used, and the decisions made by the Highveld Synod of the DRC.

1.See Van der Merwe $(2011,2014)$ for insight into similar developments in the Nederduitsch Hervormde Kerk van Afrika (NHKA)

2.This research necessitates participatory action research as the author's experience of, and ideas about, missional church has been deeply influenced by his experience in two denominational structures: as Moderator of the Highveld Synod of the DRC from 2003 to 2007, as member of the Executive of the General Synod of the DRC from 2004, as chair of the executive from 2011, and as moderato of two general synods (2011 \& 2013). 
Koffeman (2012:11-13) made a sound case for the relation between church polity and theology. The point of departure is thus that church governance, structure and polity must reflect ecclesiology, and in particular a missional ecclesiology (Van Gelder 2008a:42-43). Church polity serves the church and the theology of a specific church. A full description of the missional journey of the Highveld Synod of the DRC is beyond the scope of this research, but a discussion of the following decisions of the Highveld Synod shows that the denomination did embark on a missional journey.

\section{The Highveld Synod of the Dutch Reformed Church}

In 2005, the Highveld Synod (Sinode Höeveld) (before 2005 'Sinode Suid-Transvaal') took a number of important decisions under the heading 'Missional Synod': ${ }^{3}$

1. The Synod decides to assist its congregations to be a more missional church by (a) reaching out to communities, and (b) by attending to a ministry that provides for diversity.

2. The Synod decides to commit itself as a partner to the South African Partnership for Missional Churches.

3. The Synod decides to expand its existing call (vision statement) to the following: 'the Synod of Southern Transvaal (a) guides congregations to honour God, one another, and to serve the world with the love of Christ; and (b) guides congregations in order for the Dutch Reformed Church in Southern Transvaal to be enabled to grow into a missional church for the sake of the community' (NGK 2005:322).

The Synod also decided the following: 'The Synod accepts it as a strategic focus to assist church leadership in discerning the signs of the times, and equipping them for being a church of the future' (NGK 2005:235); and 'to be involved in the healing of our country by focussing on suffering in our society' (NGK 2005:234).

At the 2007 Synod, a full report was tabled on the activities of the South African Partnership for Missional Churches (SAPMC), as well as all developments since the Synod had decided to become a full partner of the SAPMC (NGK 2007:56-60).

The important policy decision by the General Synod of the DRC in 2013 must also be taken into account in the development of the Highveld Synod, first of all because of the close relationship between regional and general synods, and also because of the reciprocal influence between these two structures on their particular missional journeys. ${ }^{4}$ The General Synod accepted a new policy document, called Raamwerkdokument oor die Missionale aard en roeping van die

\section{Afrikaans - "Gestuurdheid van die Sinode"}

4.The missional changes of the General Synod have been discussed in detail in Niemandt (2014). In 2011 a policy document - Missional Ecclesiology - was tabled at the General Synod (NGK 2011:130-141). This document was the culmination of a study process over nearly nine years. It is a significant development in DRC ecclesiology and polity, and is itself a fully-fledged ecclesiology (Niemandt 2014:73).

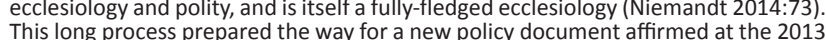
This long process
General Synod.
NG Kerk (Framework document on the missional nature and calling of the DRC) (NGK 2013d). The goal of the report was stated to be 'the creation of new missional language that may ignite new imagination for the DRC' (NGK Agenda 2013a:200). ${ }^{5}$

The policy document can be summarised as a comprehensive recalibration of the self-understanding of the DRC in terms of a missional church perspective. The core of the challenge facing denominations in changing contexts is the issue of identity (self-understanding) (Van der Merwe 2014:3 of 13). Van Gelder's (2008a:43) summary of the self-understanding of a missional church, where he argues that a missional church 'exists as a community created by the Spirit that is missionary by nature in being called and sent to participate in God's mission in the world', is echoed in the policy document. The DRC (NGK 2013c) says: 'The church is mission and participates in God's mission', and:

[T] he church is the people of God, the body of Christ and the temple of the Holy Spirit. Everything that it is and does its identity, mission and ministry - is dependent upon this relationship. (p. 5)

The Highveld Synod gathered shortly after the 2013 General Synod, and the following decisions of the 2014 Synod illustrate the development in its missional identity:

The Synod approves the continuation of the development towards being a Missional Church, utilising the following five strategies:

1. Awareness processes for congregations to understand the need for cultural change from maintenance to missional, as well as the beneficial future of a missional imagination versus the dangers of a continuation of the status quo.

2. Inspiration to participate and support missional transformation.

3. The transfer of knowledge in terms of missional capacities and missional leadership.

4. The implementation of missional leadership and processes in local congregations.

5. Establishing sustainable transformational capacities by supporting and strengthening missional capacities and skills (NGK 2014:19-20).

To summarise: Official policy decisions and vision statements can be understood as an indicator of missional transformation in a denominational structure. The Highveld Synod has embarked on a missional journey. This is evident in terms of policy decisions, which reflect the dominant language and thus imagination - of the synod. It is also evident in the empowerment of synodical task teams to execute the

5.Synod formulated the acceptance of the new policy as follows: '21.1 The General Synod receives the policy document as a document that expresses the discernment . processes of the last ten years in the Dutch Reformed Church. These processes paid attention to the essence and thature The General synod accepts the document as part of a conversation that the denomination in creating new (missional) language, as well as facilitating new conversations and imaginative new possibilities for the future of the church' (NGK 2013d:8) 
praxis of such a journey, the recognition of the importance of a missional imagination of God's preferred future, the acceptance of the SAPMC as a partner and the scope allowed for local congregations to participate in the journey of the SAPMC.

\section{The critical role of leadership in transformation}

The missional transformation of the synodical structure raises the question of the leadership that facilitated this kind of transformation. There is no missional transformation without missional leadership. Roxburgh (1998) accentuates the importance of leadership in the missional journey by stating that:

[T] he key to the formation of missional communities is their leadership ... leadership is a critical gift, provided by the Spirit because, as the Scriptures demonstrate, fundamental change in any body of people requires leaders capable of transforming its life and being transformed themselves. (p. 183)

Current research values leadership as the most important contributing factor towards the formation of a missional congregational culture (e.g. Barrett 2004:x-xi; Cordier 2014:186-190; Hendriks 2009:117; Keifert 2007:86; Sheridan \& Hendriks 2013:328-329), and this is equally important in the case of denominational transformation.

Missional leadership can be defined as the Spirit-led transformation of people and institutions, by means of meaningful relations, to participate in God's mission (Niemandt 2013:41). Missional leadership is transformative leadership. It ignites and drives change; starting with the inner transformation of the leader, leading to the transformation of the church as well as the context wherein the church finds itself.

\section{Trinitarian and pneumatological - in the power of the spirit}

Transformational leadership must always be understood in terms of a Trinitarian and pneumatological perspective. Missional leadership is living in the Trinity, because a missional church is founded and energised by life within the Trinity. This means that the church in mission can only be sustained by being spiritually deeply rooted in the Trinity's communion of love. So, even though our encounter with the triune God is inward, personal and communal, it should also direct us outward in missionary endeavour; for we are led by the Spirit into various situations and moments, into meeting points with others, into spaces of encounter and into critical locations of human struggle (World Council of Churches [WCC] 2013:57). The WCC (2013:74) stated: 'We affirm that mission begins with God's act of creation and continues in recreation, by the enlivening power of the Holy Spirit.' Mission provokes in us a renewed awareness that the Holy Spirit meets us and challenges us at all levels of life, and brings newness and change to the places and times of our personal and collective journeys. The triune God calls and sends the church, through the Spirit, into the world to participate fully in God's mission (Van Gelder 2008b:3). This means that missional leadership can only be transformational leadership if the role of the Holy Spirit is acknowledged, as only the Spirit can bring real missional transformation.

The ideas developed by researchers into 'complex leadership' create the opportunity to formulate a frame of thinking that incorporates the imperative of transformational leadership with complex systems theory and missional ecclesiology.

\section{Complex leadership as the way forward for transformational missional leadership in denominations}

\section{The church as a complex organic system}

The denominational church is one of the primary expressions of the visible, institutional church (Van Gelder 2008a:12). ${ }^{6}$ The church and denominational structures are complex systems; first of all not in terms of organisational theory but, primarily, because the church finds its identity in the activity of the Holy Spirit (Peterson 2013:5). Reflection on the church begins with the agency of the Holy Spirit, in itself in the movement of God's economy, the missio Dei. The church is thus both a divine and human reality. The WCC states, in its new policy document, Together towards life: Mission and evangelism in changing landscapes (WCC 2013:54), that the Holy Spirit works in mysterious ways beyond our imagination. The Holy Spirit is present with us, yet never domesticated or tamed (WCC 2013:58). Through Christ in the Holy Spirit, God indwells the church, empowering and energising its members. The church, in the grip of the power of the Holy Spirit, finds itself in dynamic and transformational space created by the Spirit; and change in the church will be unexpected and from the margins. The WCC (2013:74) affirms that spirituality is the source of energy for mission and that mission in the Spirit is transformative. Not only the church, but the kingdom of God, is best described as a complex system. Joubert (2013:125) argues: 'The kingdom of God is a subversive, upside-down empire. It is a relationally driven, evolving environment in constant flux. It is complex, but not unintelligible or complicated ...'

According to Doornenbal (2012:154), complexity theory provides attractive ways of thinking about the church. Sweet (2009:43) reasons from the organic nature of the church and emphasises the nature of the congregations as self-organising, complex, adaptive, self-regulating systems. According to Joubert (2013:125), complex systems involve non-linear processes, which are open to random externalities capable of generating rapid transformational change. He argues that the behaviour of complex systems cannot be forecast with certainty, or separated into component parts, since those parts are changed by their interaction. Brewin (2013:loc. 1096-1280)

6.Van Gelder (2008b:9) states that denominations are a fact of life in Christianity. $\mathrm{He}$ says (2008b:10-11): 'Denominations are not going to go away; however, they are going to continue to morph within our ever-changing context.' 
uses complexity theory in his description of the Christian faith and the church. He notes the following characteristics of emergent systems:

- They are open to their environment: sensing it, responding to it. They have blurred boundaries rather than fixed lines, and are characterised by disequilibrium rather than homeostasis, in order to respond to and engage with its environment. (loc. 1061)

- They adapt themselves to its unique and localized needs. They will be open places, fully engaging with the environment that is hosting it; sensing it, responding to it, learning from it, always seeking to change and evolve (loc. 1111).

- They are learning systems in a cycle of sensing, learning, adapting, and changing. (loc. 1129)

- They have distributed knowledge that is dispersed over a large variety of agents. (loc.1221)

The church is a complex emergent system. ${ }^{7}$ In terms of organisational theory, a denomination can be regarded as a complex organic system, as described by Plowman et al. (2007). They argue that emergent self-organisation is a central principal of complexity theory. Systems achieve order because multiple local agents interact, and those interactions produce unintended outcomes - without the intervention of a central controller. Thus organisations take on properties and structures that are unexpected, because people and groups interact, and the results of these interactions produce perpetual novelty (Plowman et al. 2007:342). They describe complex organisations as follows:

1. they are made up of many agents who act and interact with each other in unpredictable ways

2. they are sensitive to changes in initial conditions

3. they adjust their behaviour in the aggregate to their environment in unpredictable ways

4. they oscillate between stability and instability

5. they produce emergent actions when approaching disequilibrium. Additionally, complex systems are dynamic and non-linear, and rarely explained by simple cause-effect relationship (Plowman et al. 2007:342-343).

The question is: What is the role of leadership in such complex systems? And, what is the role of leadership in the missional transformation of the Highveld Synod?

\section{The role of leadership in systems where change often emerges in unexpected ways}

Plowman et al. (2007:341) argue that:

Traditional views of leadership grew out of the long-held view of organizations as equilibrium-seeking systems whose futures are knowable, and arrived at by leaders who plan interventions and control behaviors. (p. 341)

7.All social systems tend by their very nature and composition to make for even more complexity. Even in religious circles, it is self-perpetuating and expansive (Joubert 2013:117).
The implication is that any recognition of the unexpected and dynamic ways of the Spirit will also challenge a linear and mechanistic view of the church, because of the surprising work of the Spirit. Joubert $(2013: 117)$ argues that the default position of church leaders is to consider it their responsibility to create unity, clarity, order, stability and a shared purpose for people in church. This notion is challenged by the increasingly fluid new world that leans more towards the other side. It favours new forms of complexity, openness, disruption, uncertainty, self-discovery and non-linear change, which also calls for different roles for leadership than is typically presented.

What, then, is the role of leadership in a complex organisation such as denominational structures? If leaders, even church leaders, cannot predict and control the organisation's future, what can leaders do? How did the Highveld Synod happen to embark on a missional journey? Plowman et al. (2007) researched the way leadership functions in complex organisations, and found the following three mechanisms used by leaders in emergent, self-organisation systems:

1. leaders disrupt existing patterns

2. they encourage novelty

3. they act as sensemakers. (p. 347)

The mechanisms used by leaders in complex systems will now be described in terms of the research of Plowman et al., whilst this research will also apply the insights to denominational structures by means of reflection as a participatory researcher in a synodical structure, in terms of these mechanisms and the actions associated with them.

\section{Disrupting existing patterns Disruption in complex leadership}

Plowman et al. (2007:348) say complexity theory perspective suggests that leaders play a role in destabilising systems by disrupting existing processes or patterns of behaviour, thereby 'pushing the systems towards chaos or regions of complexity.' They describe two important actions by complex leaders that disrupt existing patterns:

1. Leaders create and highlight conflict. Plowman et al. (2007) found that leaders were often in the centre of conflict. They say:

Complex leaders enable emergent futures by disrupting patterns through the use of conflict and uncertainty; whereas traditional leaders create knowable futures by minimizing conflict and eliminating uncertainty. (p. 347)

Joubert (2013:118) warns against the approach in religious circles based on the premise that with more order and knowledge we can increasingly predict as well as effectively plan for the future. This ignores the rudimentary characteristic of complex societies. Leaders need to embrace uncertainty. Leaders initiate conflict by communicating the emerging new future of the organisation, which introduces further disruptions into the system. Leaders use public forums that encourage new 
agents into the system, highlight the conflicts amongst existing agents and help push the system further from equilibrium. In doing so, the leaders create and surface conflict that adds instability into the system, thereby enabling emergent self-organisation (Plowman et al. 2007:348). This type of leadership is clearly not linear, but open, interactive and challenges boundaries. Nell (2014:15) has argued for the importance of church leaders crossing boundaries, especially in the South African context; and Joubert (2013:130) says leaders view boundaries as 'permeable membranes' in order to allow people to move in and out without ever feeling threatened.

2. Leaders acknowledge uncertainty. Leaders do not back away from the uncertainties facing the organisation, but rather force the participants in systems to face its troubling future. One of the case studies described by Plowman et al. (2007) focuses on a local congregation. They describe the leadership in this church in terms of frank discussions about the future of the church:

Their openness and active engagement in conversations about the status of the church and its unlikely future put information and opinions into the system that seemed to destabilize it further, making it more likely that a new order could emerge. (p. 349)

\section{Disruption in the Dutch Reformed Church}

The actions of conflict and acknowledgement of uncertainty are evident in the case study. Conflict and a diversity of viewpoints are definitely present in the DRC. There is the very visible narrative of intense conflict, due to paradigm-shifting choices on gay-gender, church unity and confessional issues. ${ }^{8}$ Even on a fundamental level, the DRC itself is a church comprised of diverse beliefs and convictions.

The question is whether leadership created and highlighted conflict. The answer to this can be found in a number of 'conflict stories':

- The recognition of conflict in the DRC, as can be seen from the intense debates in the official mouthpiece of the DRC, Die Kerkbode, on gay-and-gender issues, church unity and the confession of Belhar.

- The inherent conflict brought about by the acknowledgement that the church is in transition. At the Highveld Synod, the report of the executive was introduced with reference to the 'storms' the DRC is experiencing. The introduction referred to the cultural shifts in society, and the need for the DRC to transform (NGK 2005:234).

- Two books were published that paid considerable attention to the idea of contextual storms and the church in transition - Nuwe drome vir nuwe werklikhede (Niemandt 2007), and Die perfekte storm (Joubert 2007).

Integrating the insights of Plowman et al. into the impact of conflict on the DRC, the question is whether church leadership brought visibility to the emerging new future of 8.See, for example, the issues on the confession of Belhar (NGK 2013b). the church. The executive of the Highveld Synod decided to work with a paradigm that focuses on God's preferred future for the church, and to bring hope in times of uncertainty (NGK 2007:12). The 2014 Synod decided to implement practical steps to create an awareness amongst its congregations to understand the beneficial future of a missional imagination versus the dangers of the status quo (NGK 2014:19-20). These decisions were orientated towards the future role of the Highveld Synod.

The second issue is whether leadership acknowledges uncertainty. The Highveld Synod chose a set of values that included the following: To embrace risks, to allow each other to make mistakes, and to acknowledge that the church does not have all the answers to the issues posed by changing contexts (NGK 2007:12). This represents a clear agreement between leaders to accept and embrace uncertainty.

\section{Encouraging novelty Encouraging novelty in complex systems and the church}

Plowman et al. (2007:347) describe the difference between 'complex leaders' and 'traditional leaders' in terms of risk-taking and innovation: Traditional leaders operate as controllers, by leading through command and control. They believe in the importance of a vision and the importance of communicating a clear vision. Complex leaders encourage innovation, establish simple rules and act as enablers of emergent self-organisation by encouraging innovation. Leaders must be revolutionaries in the strategy-making process (Ungerer 2009:23). Plowman et al. (2007) describe it as a paradoxical leadership approach:

On the one hand, the leaders tried to do what they thought 'good' leaders would do - articulate a vision and get others to buy into it. On the other hand, with something of a laissez faire attitude, they encouraged church members who had an interest in a particular program or ministry to get together with others sharing that interest and to try it. (p. 350)

Creativity and imagination are closely linked to the work of the Spirit, and a lack of creativity indicates a reduced understanding of God, as well as an underestimation of the unpredictability of the Spirit's presence (Niemandt 2012a:7). This calls for the reactivation of our underutilised imaginations, for imagination empowers us to see differently. The imagination enables us to see alternatives - a muchneeded skill in the new, globalised 'flat' world (Friedman 2006) - a world in which a new age of creativity has dawned. This seeming 'chaos of cultural change' is actually

a God-given space for creative innovation, acknowledging that the church is summoned by God to discern a pattern for living the gospel that is appropriate for our creative age. This new age of creativity does not necessarily demand detailed analysis, but rather big-picture thinking, systemic approaches, non-linear dynamics and synthesis. (Niemandt 2012a:15)

This imagination of communion means to live, understand and describe God's preferred future. It is the kind of imagination that enables a leader to tell an alternative story about the new 
possibilities already present where the Spirit is working. (Niemandt 2012a:14)

The researchers of 'The role of leadership in emergent selforganization' observed three phenomena at work in encouraging innovation. The first was the establishment of a few simple rules. Complex leaders are clear about the core issues, but ambiguous in terms of the rules as to how to achieve them. Plowman et al. (2007:350) conclude: 'What we saw was a tenacious rigidity about the principle, and complete flexibility about how to go about carrying out the principle.'

The second is what they call 'swarm behaviour of membership and staff' Plowman et al. (2007:351). They refer to the 'swarm intelligence' found in social insects such as bees, termites, and ants and found that it is also observable in organisations, when complex collective behaviour emerges from individuals who follow simple rules. ${ }^{9}$ The implication is that people in organisations can solve difficult problems (like how to turn around a dying church) even though each local interaction might be very simple. Niemandt (2012a:7) argued that missional leadership recognises that multiple perspectives and talents are needed to solve the challenges the organisation faces. Leadership is a team function - Osmer (2008:26) argues a strong case for collaborative leadership. Wheatly and Frieze (2011:16) emphasise a style of leadership in a complex world where the leader provides conditions and good group processes for people to work together. Missional authority does not focus on the individual, but on the faith community and their collective participation in the process of faithful distinction.

The third element is the promotion of non-linear interactions and emotional connections amongst people; rich and meaningful interactions that can lead to unexpected and mutually supportive outcomes (Lichtenstein \& Plowman 2009:623). Complex systems are relationally driven (Joubert 2013:125). This relational approach to leadership is essential for the emergence of novelty and creativity anything that enhances interaction will enhance the potential creativity of the system (Plowman et al. 2007:351). Heimans and Timms (2014) argue that the case for a collaborative approach is to:

$[R]$ einforce the human instinct to cooperate (rather than compete) by rewarding those who share their own ideas, spread those of others, or build on existing ideas to make them better.

Breedt and Niemandt (2013:4 of 9; 8 of 9) state in clear terms: 'If leadership is about anything, it is about relationships ... Relationships are not something the church does. Relationships are what faith is'. They say that 'effective leadership has to do with the ability of the leader to create positive relationships within an organisation.' Relationships have the power to unleash the potential of the individual

9. Heimans and Timms (2014) describe this as the power of the 'crowd'. It celebrates the power of the crowd: 'This is where we find established peer-driven players, the power of the crowd: 'This is where we find established peer-driven players,
like Wikipedia, Etsy, and Bitcoin, and newer sharing-economy start-ups, like Lyft and like Wikiped
Sidecar.' together with that of the organisation (see also Hirsch \& Catchim 2012:loc. 2275).

\section{Encouraging novelty in the Dutch Reformed Church}

As we have seen, Plowman et al. refer to the importance of the establishment of a few simple rules. They explain it as clarity about the core issues, but ambiguity in terms of the rules as to how to achieve them. The context of the Highveld Synod can be described as a system where a multitude of rules dominate, in terms of the rules and regulations contained in the church order - the rulebook of the DRC. Analysing the minutes of the Highveld Synod, it becomes clear that there was a conscious suspension of some of these rules, and perhaps even cases where a blind eye was turned to the multitude of rules that usually govern meetings. In many cases, the start of synod meetings was delayed to rule on issues involving the church order (NGK 2005:228, 237). These actions can be interpreted as an implicit process to simplify the rules of the Synod so as to enable it to focus on the core issues.

Looking back on the processes involved in decisionmaking in the Highveld Synod, big-systems technology and procedures were used in meetings since 2003. Big-systems can be described as the utilisation of swarms. The Highveld Synod used the services of two big-system consultants Marius Ungerer and Johan Herholdt (see Ungerer 2009 for a description of the big-systems theory implemented in the Synod). Ungerer (2009) describes the process in the synod as follows:

[T]hey decided to use a more conversational method for discussions by participants - the so-called Large Group Interactive Event. This allowed the collective wisdom of participants to emerge and guided the organic formation of consensus, leading to decisions that 'stuck' and therefore got actioned. (p. 32)

In terms of the promotion of non-linear interactions and emotional connections amongst people, a huge relational shift accompanied the change in discernment processes. Ungerer (2009) describes the processes followed in the Highveld Synod in relational terms:

The above outcomes were achieved through intense dialogue between participants within a context of respect for, and a willingness to listen to, each other in a new way. The main approach for this first work session was to create a hospitable space for participants to connect to each other. (p. 32)

Ungerer (2009) even concluded, in an evaluation of one of the synods, that:

Meeting each other as human beings (rather than representatives of some special taskforce or church-political point of view) had all the positive results one can expect and set the scene for a very different kind of strategy session. (p. 31)

These techniques and processes have been used in all the synod meetings from 2003 onwards, and the influence of these processes in the establishment of non-linear interactions 
and emotional connections that support transformational leadership seems evident.

\section{Sensemaking}

\section{Encouraging sensemaking in complex systems and the church}

'Sensemaking' is the process by which individuals 'construct meaningful explanations for situations and their experiences within those situations' (Plowman et al. 2007:351). Brewin says that the role of leaders in a complex organisation is to 'change the perceptions of a situation' (Brewin 2013:loc. 1311). Leaders as sensemakers are very important - leaders must be able to scan the environment and interpret issues that might influence decision-making and strategic change in organisations. Leaders must give meaning to unfolding events. Osmer (2008:24) says leaders must guide the congregation as a community of interpretation. Brewin (2013:loc. 1201) argues that they must make connections, must try new things 'always sensing, getting feedback, adapting, and remembering.' Joubert (2013:126) argues that leaders must be able to assimilate complex ideas, systems, problems, situations, interactions, or relationships. He says leaders must uniquely address the impasse of religious institutions to adapt effectively to change, by infusing new life into existing forms of religious expression in order to bind the family of God together in meaningful, collective experiences of his transcendent reality (Joubert 2013:129).

Discernment is the core practice of a missional church seeking the presence or movement of the triune God in relationship with all of creation (Niemandt 2012b:6 of 9). Discernment leads to new insights - in terms of the self, the other and God (Van der Merwe 2014:11 of 13). It is an issue of textual and contextual exegesis, where a church discerns what God is doing in, through and amongst all the movements of change in which it finds itself (Roxburgh \& Romanuk 2006:24). Discernment is the art of reading the times and signs.

Plowman et al. (2007:351) found that leaders are involved in two sensemaking activities: (1) assuming the role of a 'tag', and (2) creating correlation through language.

The role of a 'tag' boils down to the ability to focus attention on core issues; that is, leaders give meaning to emergent events by reframing them. ${ }^{10}$ According to Plowman et al. (2007:352), tags enable specific behaviours by directing attention to what is important: 'A leader becomes a tag when others recognize them as a symbolic reference for their corresponding message.'

Complex leaders become enablers of emergent selforganisation by being sensemakers through correlation, and this is done by the creation of correlation through language. Sensemaking is being accomplished in part through

10.According to Lichtenstein and Plowman (2009:625) a tag is an identifier for a valued set of behaviours; as such a tag directs attention to things that are important, giving meaning to actions that might otherwise go unnoticed. linguistic and communicative processes (Brown, Colville \& Pye 2015:266). 'Leaders manage words rather than manage people' (Plowman et al. 2007:347). The language of leaders is a powerful organisational tool both for articulating meaning and collective action. Leaders use language to help give meaning to unfolding events. Leaders interpret emerging events rather than direct events. Plowman et al. (2007:352) found that with language as a medium, leaders can 'establish the identity of the objects, events, and actors that constitute their social environment.' Joubert (2013:119) recognises the important role of language and warns that leaders are often left with a 'verbal repertoire' that stimulates 'vertical' rather than 'lateral' orientations, as well as with a large vocabulary for issues related to order, fear and conformity rather than flexibility, risk, exploration and fluidity. In such cases, the church becomes a prisoner of language that prevents the church from seeing, hearing, or learning in creative new ways. By using a consistent language, leaders give meaning to the changes that are underway. Wheatly and Frieze (2011:16) stress the importance for leaders to host meaningful conversations that create the means for problems to get solved, for teams to function well and for people to become energetic activists. One of the most transformative applications of language is the use of narrative. Brown et al. (2015:268) argue that stories are active constructions of embedded participants' local 'realities' and 'a potent tool for meaning-making.' Narrative has the ability to form and transform individuals, congregations and communities and is especially appropriate for mainline denominations (Van der Merwe 2014:8 of 13). Transformative missional leadership demands narrative. A missional ecclesiology demands a new story (Niemandt 2013:127).

\section{Sensemaking in the Dutch Reformed Church}

Plowman et al. (2007:352) argue that leaders give meaning to emergent events by reframing them. They enable specific behaviours by directing attention to what is important. Ungerer (2009) reflects on the processes in the Highveld Synod:

This different conversation is being shaped by a biblical and theological imagination for understanding the very nature of the church. The key premise is that understanding the nature of the church is foundational for being able to clarify the purpose of the church, and for developing any strategies related to that purpose. And understanding the nature of the church is also seen as being foundational for discerning how to address changing cultural contexts. (p. 32)

It is clear that a process of 'reframing' occurred in the Highveld Synod, and that the simultaneous introduction of the insights of the SAPMC, as well as the ideas of the Gospel in our Culture Network (and other inputs from the missional church movement), provided a timely theological reframing of the self-understanding of the Highveld Synod.

This process of sensemaking was undergirded by the emergence of a missional spirituality. A missional church is characterised by a missional spirituality. This is a transformative spirituality (WCC 2013:57) that gives meaning 
to our lives and stimulates, motivates and gives dynamism to life's journey. Missional spirituality is a spiritual awareness of God's presence, and of life in the Trinity. As the triune God is active in giving and receiving love, joy and delight within the Godhead, we are invited to participate in this giving and receiving. It is this movement of worship and mission that allows us to view leadership as a participative activity (Horsthuis 2011:94). It is an imperative in the journey of transformation and being transformed.

The creation of a new language also plays a very important role in sensemaking. Leaders manage words rather than people. Language plays a very important role in the missional transformation in congregations, according to Niemandt (2010:408): 'This new language created the understanding that things have changed in the congregation. The new language seems to be a dominant expression of organic change.' Joubert (2013:130) describes this as the 'intentional editing' of fellow believers to 'metanoetically write and act out new stories in God's kingdom.' This is equally important in denominational structures. A number of theologians and writers have visited South Africa since 2002 and have played an important role in shaping a new missional language in the DRC. ${ }^{11}$

\section{Conclusion}

Bullock's (2008:105) argument that the relationship between identity and mission is the key to unlocking the future for mainline denominations is completely appropriate for the DRC and the Highveld Synod. Transformational leadership is the key to the establishment and internalisation of this relationship. The case study confirmed the theory developed by Plowman et al., and underlined the importance of actions of leadership in the complex system of a church denomination, where leaders disrupt existing patterns, encourage novelty and act as sensemakers. These patterns can serve as guidelines in the continuous missional transformation of the denomination and the church at large.

\section{Acknowledgements Competing interests}

The author declares that he has no financial or personal relationships which may have inappropriately influenced him in writing this article.

\section{References}

Barrett, L.Y. (ed.), 2004, Treasure in clay jars: Patterns in missional faithfulness, Eerdmans, Grand Rapids, MI.

Breedt, J.J. \& Niemandt, C.J.P., 2013, 'Relational leadership and the missional church', Verbum et Ecclesia 34(1), Art. \#819, 9 pages. http://dx.doi.org/10.4102/ ve.v34i1.819

Brown, A.D., Colville, I. \& Pye, A., 2015, 'Making sense of sensemaking', Organization Studies 36(2), 265-277. http://dx.doi.org/10.1177/0170840614559259

11.The following must be mentioned: As guests of the Highveld Synod - Prof. Patrick Keifert, Prof. Leonard Sweet, Alan Hirsch, Brian McLaren, and Dr Tony Jones. As
guests of the General Synod - Prof. Patrick Keifert, Alan Hirsch, Prof. Stefan Paas, Dr guests of the General Synod - Prof. Patrick Keifert, Alan Hirsch, Prof. Stefan Paas, Dr
Martin Robinson, and Alan Roxburgh. The following local theologians also played a significant role: Prof. Malan Nel, Prof. Jurgens Hendriks, Dr Coenie Burger, Dr Frederick Marais, Prof. Stephan Joubert, the late Prof. Jannie Swart, Dr Chris van Wyk and Rev. Danie Mouton.
Brewin, K., 2013, The complex Christ: Signs of emergence in the urban church, e-edn., Vaux.

Bullock, M.W., 2008, 'The challenge of developing missional denominational agencies and the implications for leadership', in G. van Gelder (ed.), The missional church \& denominations. Helping congregations develop a missional identity, pp. 104-130, Eerdmans, Grand Rapids, MI.

Coetzee, M.H. \& Conradie, E.M., 2012, 'Dominante dogmatiese sleutels in die Ned Geref Kerk na 1974', Nederduitse Gereformeerde Teologiese Tydskrif 53(3/4), 90-108.

Cordier, G.S., 2014, 'Kernkapasiteite van die predikant as missionale leier in die vorming van'n missionale gemeentekultuur', PhD proefskrif, Dept. Godsdiens- en sendingwetenskap, Universiteit van Pretoria.

Cordier, G.S. \& Niemandt, C.J.P., 2015, 'Core capacities for the minister as missional leader in the formation of a missional congregational culture, Pt. 1, Role of a minister', Journal of Missional Practise, Winter, viewed on 14 March 2015, from http://journalofmissionalpractice.com/index.php/current-issue-experiment-andinnovation/gert-s-cordier-and-cornelius-j-p-niemandt

Creswell, J.W., 2015, A concise introduction to mixed methods research, SAGE Publications, Thousand Oaks, CA. (Kindle edn., Sage Mixed Methods Research).

De Vos, A.S. (ed.), 1998, Research at grass roots: A primer for the caring professions, Van Schaik, Pretoria.

Doornenbal, R., 2012, Crossroads: An exploration of the emerging-missional conversation with a special focus on 'missional leadership' and its challenges for theological education, Eburon, Delft.

Dutch Reformed Church (DRC) see Nederduitse Gereformeerde Kerk (NGK)

Friedman, T.L., 2006, The world is flat: The globalized world in the twenty-first century, Updated and expanded edn., Penguin, London.

Heimans, J. \& Timms, H., 2014, 'Understanding "new power"', Harvard Business Review, December 2014, viewed 15 March 2015, from https://hbr.org/2014/12/ understanding-new-power

Hendriks, H.J., 2009, 'Trauma and conflict as prerequisites for identity transformation: Lessons from the South African partnership for missional churches', Nederduitse Gereformeerde Teologiese Tydskrif 50(1/2), 109-119.

Hirsch, A. \& Catchim, T., 2012, The permanent revolution: Apostolic imagination and practice for the 21st century church, Jossey-Bass, San Francisco, CA. (Kindle edn.)

Horsthuis, J., 2011, 'Participants with God: A perichoretic theology of leadership', Journal of Religious Leadership 10(1), 81-107.

Joubert, S. (ed.), 2007, Die Perfekte Storm, CUM, Vereeniging.

Joubert, S., 2013, 'Not by order, nor by dialogue: the metanoetic presence of the kingdom of God in a fluid new world and church', Acta Theologica 33(1), 114-134. http://dx.doi.org/10.4314/actat.v33i1.6

Keifert, P., 2007, Ons is nou hier. 'n Nuwe era van gestuur-wees: 'n Missionale ontdekkingsreis, Bybel-Media, Wellington.

Koffeman, L.J., 2012, Het goed recht van die kerk: Een theologische inleiding op het kerkrecht, Kok, Kampen.

Lichtenstein B.B. \& Plowman, D.A., 2009, 'The leadership of emergence: A complex systems leadership theory of emergence at successive organizational levels', The Leadership Quarterly 20(4), 617-630, viewed 13 May 2015, from http://0-www. sciencedirect.com.innopac.up.ac.za/science/article/pii/S104898430900099X

Nederduitse Gereformeerde Kerk (NGK), 2011, 'Agenda vir die 14de vergadering van die Algemene Sinode van die Nederduitse Gereformeerde Kerk 2011', 10-14 Oktober 2011.

Nederduitse Gereformeerde Kerk (NGK), 2013a, 'Agenda vir die 15de vergadering Algemene Sinode van die Nederduitse Gereformeerde Kerk 2013',06-10 Oktober 2013.

Nederduitse Gereformeerde Kerk (NGK), 2013b, 'Algemene Sinode 2013 van NG Kerk se besluit oor die belydenis van Belhar', viewed 16 March 2015, from http://www. belydenisvanbelhar.co.za

Nederduitse Gereformeerde Kerk (NGK), 2013c, 'Framework document on the missional nature and calling of the DRC', viewed 04 January 2015, from http:// ngkerk.org.za/wp/index.php/english/documents/missional-nature-and-callingof-the-dr-church/

Nederduitse Gereformeerde Kerk (NGK), 2013d, 'Notule vir die 15de vergadering van die Algemene Sinode van die Nederduitse Gereformeerde Kerk', 06-10 Oktober 2013.

Nederduitse Gereformeerde Kerk (NGK), Sinode Hoëveld, 2005, 'Handelinge van die Sinodesitting', 18-20 Oktober 2005.

Nederduitse Gereformeerde Kerk (NGK), Sinode Hoëveld, 2007, 'Agenda', 25-27 Oktober 2007.

Nederduitse Gereformeerde Kerk, Sinode Hoëveld, 2014, 'Notule van die 21ste vergadering', September 2014

Nell, I.A., 2014, 'Transforming congregational culture sub-urban leadership perspectives within a circuit of the DRC', paper delivered at the second conference of the international research project with the working title: 'Transforming religious identities and communities at the intersections of the rural, the urban, and the virtual', that took place on 02-04 July 2014 at the Vrije Universiteit in Amsterdam, The Netherlands, viewed 05 January 2014 from http://www.kaapkerk.co.za/wp/wp-content/uploads/2013/04/lan-NellTransforming-congregational-culture.pdf

Niemandt, C.J.P., 2007, Nuwe drome vir nuwe werklikhede, LuxVerbi BM, Wellington.

Niemandt, C.J.P., 2010, '5 Years of missional church - reflections on missional ecclesiology', Missionalia 38(3), 397-413. 
Niemandt, C.J.P., 2012(a), 'Missional leadership - entering the trialogue', inaugural address of Professor CJP (Nelus) Niemandt as head of the Department Science of Religion and Missiology, 09 May 2012, viewed 04 January 2015, from http:// repository.up.ac.za/handle/2263/18785

Niemandt, C.J.P., 2012(b), 'Trends in missional ecclesiology', HTS Teologiese Studies/ Theological Studies 68(1), Art. \#1198, 9 pages. http://dx.doi.org/10.4102/hts. v68i1.1198

Niemandt, C.J.P., 2013, Nuwe leiers vir nuwe werklikhede: Insigte wat nodig is om die nuwe uitdagings in die kerk en die lewe te hanteer, Christelike Uitgewersmaatskappy, Vereeniging.

Niemandt, C.J.P., 2014, 'Emerging missional ecclesiology in the Dutch Reformed Church in South Africa and church polity', in A. Janssen \& L.J. Koffeman (eds.) Protestant church polity in changing contexts. Ecclesiological and historical contributions. Proceedings of the international conference, vol. 1, pp.65-82, Utrecht, The Netherlands, 07-10 November 2011, Zürich, LIT-Verlag.

Osmer, R.R., 2008, Practical theology: An introduction, Eerdmans, Grand Rapids, MI.

Peterson, C.M., 2013, Who is the church? An ecclesiology for the twenty-first century, Fortress Press, Minneapolis, MN. (Kindle edn.)

Plowman, D.A., Solansky, S., Beck, T.E., Baker, L., Kulkarni, M. \& Travis, D.V., 2007, 'The role of leadership in emergent selforganization', The Leadership Quarterly 18(4), 341-356, viewed 12 May 2015, from http://0-www.sciencedirect.com.innopac. up.ac.za/science/article/pii/S1048984307000707

Roxburgh, A.J., 1998, 'Missional Leadership: Equipping God's People for Mission', in D.L. Guder (ed.), Missional church: A vision for the sending of the church in North America, pp. 183-220, Eerdmans, Grand Rapids, MI.

Roxburgh, A.J. \& Romanuk, F., 2006, The missional leader: Equipping your church to reach a changing world, Jossey-Bass, San Francisco, CA.
Sheridan, T.M. \& Hendriks, H.J., 2013, 'The missional church movement', Nederduitse Gereformeerde Teologiese Tydskrif 54(3/4), 319-332.

Sweet, L., 2009, So beautiful: Divine design for life and the church, David Cook, Colorado Springs, $\mathrm{CO}$.

Ungerer, M., 2009, 'Hosting strategic conversations: Some alternative approaches for leaders', Journal of Global Strategic Management 3(1), 23-37, viewed 06 January 2015, from http://www.isma.info/uploads/files/023-hosting-strategicconversations-some-alternative-approaches-for-leaders.pdf

Van der Merwe, J.C., 2011, 'Missionale gemeentes in die Nederduitsch Hervormde Kerk van Afrika - Teologies verantwoord', HTS Teologiese Studies/Theological Studies 67(3), Art. \#1094, 9 pages. http://dx.doi.org//10.4102/hts.v67i3.1094

Van der Merwe, J.C., 2014, "n Narratief vir kerk-wees vandag', HTS Teologiese Studies/ Theological Studies 70(1), Art. \#2699, 13 pages. http://dx.doi.org/10.4102/hts. v70i1.2699

Van Gelder, G., 2008a, 'An ecclesiastical geno-project: unpacking the DNA of denominations and denominationalism', in G. van Gelder (ed.), The missional church \& denominations: Helping congregations develop a missional identity, pp. 12-45, Eerdmans, Grand Rapids, MI.

Van Gelder, G., 2008b, 'Introduction: Engaging the missional church conversation', in G. van Gelder (ed.), The missional church \& denominations: Helping congregations develop a missional identity, pp. 1-11, Eerdmans, Grand Rapids, MI.

Van Niekerk, A., 2014, 'The missional congregation in the South African context', HTS Teologiese Studies/Theological Studies 70(1), Art. \#2648, 6 pages. http://dx.doi. org/10.4102/hts.v70i1.2648

Wheatly, M. \& Frieze, D., 2011, 'Leadership in the age of complexity: From hero to host', Resurgence Magazine 264 (January/February), 14-17.

World Council of Churches, 2013, Resource book WCC 10th Assembly, Busan 2013, World Council of Churches Publications, Geneva. 